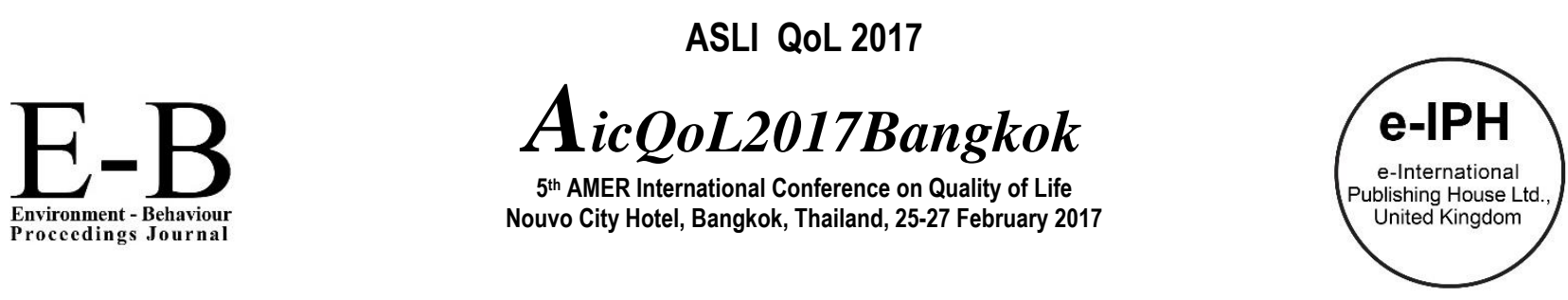

\title{
Students' Experiential Learning in Botanic Garden Leisure Setting
}

\author{
Noralizawati Mohamed ${ }^{1 *}$, Noriah Othman ${ }^{2}$ \\ 1,2Centre of Landscape Architecture, Faculty of Architecture, Planning and Surveying, Universiti Teknologi MARA, 42300 Puncak Alam, Selangor, Malaysia
}

\begin{abstract}
Botanic garden is associated with environment conservation, outdoor recreation and education programme for students. The learning opportunities that take place in the garden functions as a window of knowledge, a platform to build better understanding beside aroused cognitive skills during visitation. This study is aimed to identify the potential of Putrajaya Botanical Garden as a learning environment. The finding showed the male respondents rated higher than the female in all attributes associated with experiential learning at the garden. With good practice of design and management, this garden can continuously serves as successful educational learning environment and achieve its mission.
\end{abstract}

Keywords: Experiential learning; leisure setting; botanic garden; educational learning environment

ISSN: 2398-4287@ 2017. The Authors. Published for AMER ABRA by e-International Publishing House, Ltd., UK. This is an open access article under the CC BYNC-ND license (http://creativecommons.org/licenses/by-nc-nd/4.0/). Peer-review under responsibility of AMER (Association of Malaysian Environment-Behaviour Researchers), ABRA (Association of Behavioural Researchers on Asians) and cE-Bs (Centre for Environment-Behaviour Studies), Faculty of Architecture, Planning \& Surveying, Universiti Teknologi MARA, Malaysia.

\subsection{Introduction}

Botanic garden is known as green space that associated with environment conservation, outdoor recreation and education programme for students. The learning opportunities that take place in the garden, functions as a window of knowledge, a platform to build better understanding, and aroused cognitive skills during visitation. A lot of research identified that the science education such as arboretums and plants identification can be upgrade to another higher level, where the garden is treated as students' centre of learning and outdoor laboratory (Hensen, 2012; Mehdi and Koorosh, 2015; Packer, 2004 \& Utama, 2015).

In Malaysia, the regeneration of many urban parks to botanical gardens showed serious afford by the government to preserve plants and educate public to appreciate the landscape. During the Celebration of National Landscape Day 2016, National Landscape Department has highlighted that all parks should be designed to promote educational visit and encourage visitors to learn and experience the green environment. Numbers of previous studies have agreed that the outdoor natural settings are one of the best examples that provide learning opportunity through experience and reflection (Hansen, 2012). Furthermore, this approach plays as a central role to examine users' satisfaction feeling while doing their visitation thus, these relationships are very important to be studied. However, despite their potential as an 'outdoor museum', research and experiment to uphold the potential of botanic garden as educational learning environment are still at early stage of study. Since the gardens settings have always encouraged people to learn, the quality of learning environment and informational facilities that offered in the garden should be analysed to ensure it is useful for a variety teaching activities and self-learning by the student. This study presents the importance of conducting on-site experiential learning by linking students' learning preference and educational infrastructure in garden leisure setting. This study is aimed to identify the potential of Putrajaya Botanical Garden as a learning environment. The objectives of this study are (1) to determine the factors that encourage respondents to facilitate experiential learning and (2) to determine the respondents' satisfaction level based on the existing learning facilities.

\footnotetext{
${ }^{*}$ Corresponding author. Tel.:

E-mail address: leezmohd@yahoo.com
}

ISSN: 2398-4287@ 2017. The Authors. Published for AMER ABRA by e-International Publishing House, Ltd., UK. This is an open access article under the CC BYNC-ND license (http://creativecommons.org/licenses/by-nc-nd/4.0/). Peer-review under responsibility of AMER (Association of Malaysian Environment-Behaviour Researchers), ABRA (Association of Behavioural Researchers on Asians) and cE-Bs (Centre for Environment-Behaviour Studies), Faculty of Architecture, Planning \& Surveying, Universiti Teknologi MARA, Malaysia

DOI: http://dx.doi.org/10.21834/e-bpj.v2i5.697 


\subsection{Literature Review}

\subsection{The Importance of Experiential Learning}

Experiential learning provides a holistic model of the learning process that gives added value to peoples' appreciation and knowledge improvement. And today, the practice of experiential learning is a global phenomenon and has significant impact in educating people especially in outdoor leisure setting. According to Packer (2004), this study is important to emphasize the central role of individual and society in many ways such as through play, leisure activities and visitation to museums, natural parks and gardens. Experts in attitude and behavior change advocate experiential learning as the most durable and effective strategy for producing citizens dedicated to environmental protection (Calkins, 2012), expend visitors understanding about nature (Hensen, 2012), learning flexibilities and problem- solving skills (Peterson, 2015), promotes critical thinking (Heinrich, 2015) and enhance self- esteem and boost motivations (Packer, 2004). Ballantyne et al., (2008), Chavez and Sharrock (2013) and Noriah (2015) addressed the opportunity for people to learn and gain benefits from the sense of well-being that botanical gardens provide. Lopez and Rueda (2015) found that the experiential learning as a tool for society transformation. According to them, through educational programme, workshop and course, the botanical garden has the potential to be promoted as scientific learning place or a living museum to people. People who had more contact with nature cope better with adversity (Corraliza et al., 2012) and act efficiently in health (Mehdi and Koorosh,2015).

\subsection{Relationship of Experiential Learning Theory with Landscape Learning}

Kolb explored the relationship of Experiential Learning Theory with landscape learning in 1984. He identified that this theory is a very important process where knowledge is created through concrete experience and abstract conceptualization, and transformed to reflective observation and experimentation that continues until the conclusion of project or learning outcomes. This theory also found to be related with Theory of Flow by Csikszentmihalyi in 1990. Flow can be experienced in any field of activity, for instance in sports, playing music, painting and leisure activities. As referred to Clements and Dorminey (2011), addressed that this theory has been used to provide fundamental guidelines for people to design landscape site that meaningful (landscape based-experience). In addition, landscape that included site elements that support range of activities are able to facilitate human personal skill to learn (Clement and Dorminey, 2011). Both theories have been used by many researcher and practitioners to value the quality of existing landscape in related with learning environment (Noriah et al., 2015; Hensen 2012; Peterson, 2015 and Heinrich, 2015). Their research approved that coherent landscape visuals, experiential education and effective instructional design could positively encourage experiential learning among users.

\subsection{Garden Landscape Features and Motivation to Learn}

Recent studies have highlighted the importance of landscape features in different types of landscape setting such as at the open space and neighbourhood (Marlyana et al., 2012) parks and gardens (Noriah et al., 2015) and riverside area (Hilma and Mohammad, 2016). Their research summarized that the tangible and functional landscape features could encourage people to do outdoor recreational activities and feel satisfied. Noriah et al., 2015 previously addressed in their research that elements in the garden as one of the factors that contributed to visitation. In context of learning landscape, some studies investigated that the informational landscape features such as garden and interpretative signage give opportunity to educate the visitors and encourage the learning process (Noriah et al., 2014; Hensen 2012; Ballantyne et al., 2008). Study on environmental awareness in botanical garden by Balantyne et al., (2008) suggested right information is needed to spark the interests and motivations among garden visitors to appreciate the landscape. Mehdi and Koorosh (2015) and Utama (2015) highlighted that public participation and continuous involvement are important ingredients to increase the quality of environment especially related to outdoor natural setting. According to Callejaz and Gonzalez (2015) motivation is needed to inspire the learning process especially when dealing with knowledge and practice of living plants.

\subsection{Background of Research Area}

Guided by the 'City in the Garden Concept', Putrajaya is planned to conserve and utilize its existing undulating contour for landscaped purpose- garden, lakes and parks (Putrajaya, 2016). Department of Botanical Garden is responsible and very active in conservation work within the international and national level. The Putrajaya Botanical Garden is located at Precint 1, Putrajaya and was opened to public on 2001. With more than 950 plant species around the world, this garden is well known as one of the biggest and successful botanical garden in Malaysia. The garden functions as both recreational spot and research centre for local people and tourist. The garden covers an area of 230 acres that divided into three zones; 1) Flowers Zone (63 acres), 2) Ethno Botany Zone (97 acres), and 3) Conservation and Arboretum Zone (70 acres). This botanical garden also houses a living plant collection and plant specimens at the Nursery Complex for research purposes (Purajaya, 2016). The park is highly accessible via private or public transportation hence it is often used as a venue for environmental education programs, recreational activities, researches and as an ecotourism destination. Exploring the park is made easy by the availability of the tram rides, bicycles for hire, guided tours and an excellent network for pedestrian trails (Putrajaya, 2016). The garden received a high number of visitors each year especially during weekend and public holidays and provided them with variety garden facilities such as Informational Centre, outdoor laboratory, research centre, plants facts, information and pictures, as well as jogging and bicycle track. At Putrajaya Botanical Garden, visitors can experience activities like Garden Guided Tour, Exploration Activities (Walk and Hunt, Exploration and Morphological Hunt) and educational module. The operation hours of this garden are from Tuesday to Sunday, from $9.00 \mathrm{am}$ to $6.00 \mathrm{pm}$. 


\subsection{Research Methodology}

Survey method was used to collect data in order to address the research objectives to the fullest extent possible. Hensen (2012) added that the design features of learning landscape should be addressed by the researcher in instrument making process. Landscape architecture students from semester one and semester two recently participated in the survey of learning experience at Putrajaya Botanical Garden. There were 88 respondents answered the questionnaire survey and assisted by the lecturers. The survey took place at the Visitor Interpretative Centre (VIC), Canopy Bridge, Heliconia Trail, Palm Hill and Sun Garden. The respondents were asked to answer the questions by referring to the garden's directory and follow the informational signage that provided for them. This approach was called as 'movement observation' by Peterson (2015) in his previous research.

This study was administered by using a structured designed questionnaire to collect data from the respondents. At the beginning stage, careful attention was given before designing the instrument where some observations were done to determine the places that contribute to different type of learning experience. Survey on the reaction and behavior of the visitors were also recorded to ensure that they have a similar objective while visiting the garden. The first section of the questionnaire investigated the demographical background of the respondents. Their interest to study about plants and landscape were asked under this section in order to identify their motivation level when answering the questionnaire. Following sections such as; respondents expectation before and after visit the garden, things that encourage them to learn, respondents opinion for the garden as learning place were then discovered. They were also asked to rate the photographs showing different types of learning facilities at the final section using a five -point Likert scale where 1= very agree, 2= agree, 3= moderate, 4= disagree and, 5= very disagree. Each selected photograph under these sections had both elements of landscape design and learning facilities.

\subsection{Result and Discussion}

\subsection{Respondents' Demographical Survey}

There were 88 respondents from first year Landscape Architecture Programme participated in this survey. According to Table 1 , $25.0 \%$ respondents were male while $75.0 \%$ were female. The result showed that $64.8 \%$ of them were 20 years and below and $35.2 \%$ were 21-30 years old. Under the semester categories, students from Semester One represented 69.3\% while in Semester Two represented $30.7 \%$.

Table 1: Respondents' Demographical Background

\begin{tabular}{|c|l|c|c|}
\hline & & & Frequency \\
\hline Variables & & 22 & Percentage $\%$ \\
\hline Gender & Male & 66 & 25.0 \\
\hline & Female & 88 & 75.0 \\
\hline & Total & 57 & 100.0 \\
\hline Age & 20 years old and below & 31 & 64.8 \\
\hline & $21-30$ years old & 88 & 35.2 \\
\hline & Total & 61 & 100.0 \\
\hline Semester & 01 & 27 & 69.3 \\
\hline & 02 & 88 & 30.7 \\
\hline & Total & 100.0 \\
\hline
\end{tabular}

\subsection{Interest about Landscape and Plants}

Table 2 shows the frequency results according to their interest about landscape and plants. Majority of the students showed their interest about plants and landscape. $19.3 \%$ shows that they are 'Really Interested', $58 \%$ is 'Interested', $21.6 \%$ is 'Moderate', and $1.1 \%$ is 'Not Sure'.

Table 2: Respondents' Interest about Landscape and Plants

\begin{tabular}{|c|c|c|}
\hline Interest Level & Frequency & Percent \% \\
\hline Really interested & 17 & 19.3 \\
\hline Interested & 51 & 58.0 \\
\hline Moderate & 19 & 21.6 \\
\hline Not sure & 1 & 1.1 \\
\hline Total & 88 & 100.0 \\
\hline \multicolumn{2}{|c|}{ Source: Researchers (2016) }
\end{tabular}

\subsection{Before Visitation (Respondents' Hopes from the Visit)}

Table 3 shows the respondents' hopes from the visit. The Cronbach's Alpha value for the above analysis is 0.95 . Result for highly significant different at $p<0.01$ is found for answers such as 'To socialize with others' with the male respondents rated higher (mean=4.27) and the female respondents rated lower (mean=3.73) and 'To get some ideas and use imagination' with the male respondents higher (mean=4.45) and the female respondents lower (mean=3.94).

The significant different at $p<0.05$ is found for answers such as 'To do thing with my companion' which showed the male rating is higher (mean=4.50) than the female rating (mean=4.0). 'To alleviate boredom' showed that the male rating is higher (mean=4.36) and 
the female rating is lower (mean=3.86). The above mean results concluded that the male respondents scored higher than the female respondents although the number of male respondents is lesser than the female respondents. They also have certain expectations when do the visit thus making this visit is important to them.

Table 3: Respondents' Hopes from the Visit

\begin{tabular}{|c|c|c|c|c|c|}
\hline & Variables & Male & Female & $\mathbf{F}$ & Sig. \\
\hline 1 & To feel confident about myself & 4.36 & 4.05 & 0.065 & 0.094 \\
\hline 2 & To get some ideas and use my imagination & 4.45 & 3.94 & 0.035 & $0.007^{* *}$ \\
\hline 3 & To feel happy and satisfied & 4.50 & 4.18 & 0.479 & 0.072 \\
\hline 4 & To do things with my companion & 4.50 & 4.09 & 0.852 & $0.016^{*}$ \\
\hline 5 & To satisfy my mind curiosity & 3.91 & 4.02 & 0.023 & 0.584 \\
\hline 6 & To discover more about myself & 3.95 & 3.85 & 0.047 & 0.638 \\
\hline 7 & To socialize with others & 4.27 & 3.73 & 0.541 & $0.006^{* *}$ \\
\hline 8 & To spend quality time with my family or friends & 4.32 & 3.97 & 2.482 & 0.081 \\
\hline 9 & To alleviate boredom & 4.36 & 3.86 & 0.153 & $0.018^{*}$ \\
\hline 10 & To feel more confident about my abilities & 4.09 & 3.89 & 0.075 & 0.364 \\
\hline 11 & To recover from stress and of everyday life & 4.41 & 4.12 & 1.080 & 0.107 \\
\hline 12 & To think about my personal values & 4.18 & 3.83 & 1.726 & 0.079 \\
\hline 13 & To enjoy myself & 4.41 & 4.05 & 0.501 & 0.069 \\
\hline 14 & To relax physically & 4.27 & 4.00 & 0.142 & 0.214 \\
\hline 15 & To relax mentally & 4.43 & 4.12 & 0.329 & 0.114 \\
\hline 16 & To have a change from my daily routine & 4.09 & 3.79 & 0.405 & 0.172 \\
\hline 17 & To develop close friendship & 4.52 & 4.14 & 0.007 & 0.091 \\
\hline 18 & To experience something new or unusual & 4.45 & 4.44 & 0.197 & 0.054 \\
\hline 19 & To develop my spirituality & 4.41 & 4.08 & 0.206 & 0.930 \\
\hline 20 & To understand the concept of Botanical Garden & 4.14 & 4.28 & 0.393 & 0.573 \\
\hline 21 & To use my mind & 4.23 & 4.03 & 2.087 & 0.296 \\
\hline 22 & To meet new people & 3.95 & 3.64 & 0.098 & 0.190 \\
\hline 23 & To explore new ideas & 4.23 & 4.24 & 1.659 & 0.937 \\
\hline 24 & To get away from stress of everyday life & 4.27 & 4.14 & 0.275 & 0.487 \\
\hline 25 & To do something exciting & 4.36 & 4.18 & 0.816 & 0.299 \\
\hline 26 & To expand my interest on something & 4.41 & 4.35 & 0.053 & 0.713 \\
\hline 27 & To be mentally stimulated & 4.36 & 4.23 & 1.075 & 0.423 \\
\hline 28 & To find some peace and tranquilities & 4.50 & 4.30 & 0.000 & 0.252 \\
\hline 29 & To be better informed & 4.41 & 4.23 & 0.036 & 0.310 \\
\hline 30 & To study or do research & 4.45 & 4.38 & 0.367 & 0.684 \\
\hline \multicolumn{6}{|c|}{$\begin{array}{l}\text { Source: Researchers (2016) } \\
\text { Likert scale: } \\
\text { ortant; } 3=\text { Moderate Important; 4=Important; } 5=\text { Very Important } \\
\text { *Significant different at } P<0.05 \\
\text { tighly significant different at } P<0.01\end{array}$} \\
\hline
\end{tabular}

\subsection{After Visitation (Respondents' Opinion on the Garden as Learning Place)}

The Cronbach's Alpha value for this analysis is 0.7. There is no significant differences were detected between the male and female respondents under Table 4. It can be concluded that the variables have similar rating values and not depending on the gender factors. However, the highest mean results for the above analysis shows that the male respondents preferred to 'Take a lot of Effort to Learn' with mean $=4.50$ while female respondents preferred to 'Understand the Information Presented' with mean=4.38. Both genders gave lowest rate for 'Learning here is Difficult'.

Table 4: Respondents' Opinion on the Garden as Learning Place

\begin{tabular}{|c|l|c|c|c|c|}
\hline \multicolumn{1}{|c|}{ Variables } & Male & Female & F & Sig. \\
\hline 1 & It takes a lot of effort to learn things here & 4.50 & 4.17 & 0.692 & 0.066 \\
\hline 2 & Understanding the information presented here is important to me & 4.41 & 4.38 & 2.146 & 0.843 \\
\hline 3 & Learning here is a fun thing to do & 4.45 & 4.14 & 0.002 & 0.080 \\
\hline 4 & Learning here is difficult & 3.14 & 3.02 & 1.286 & 0.667 \\
\hline 5 & The visit or tour was for educational to me & 4.38 & 4.28 & 1.620 & 0.595 \\
\hline 6 & The visit or tour was for recreational to me & 4.33 & 4.30 & 0.387 & 0.830 \\
\hline
\end{tabular}

\subsection{Respondents' Opinion on the Botanic Garden as Place that Encourage Learning Experience}

Table 5 represents the factors that encouraged the experiential learning activities and the Cronbach's Alpha value is 0.95 . The result shows significant different at $p<0.05$ for answers such as 'I had the opportunity to ask questions' with the male (mean=4.45) and female (mean=3.45), 'The information appealed to my imagination' with male (mean=4.33) and female (mean=3.94) and 'The 
information appealed to my emotions' with male (mean=4.14) and female (mean=3.74). The information provided at the garden encouraged imagination and emotion and increased curiosity about the plants. These results aligned with findings by other researchers that landscape preference is influenced by the observer's gender (de Souza Silva and Biondi, 2013). Aziz and Said (2012) carried out research on open green space. According to them, the physical factors of the space could give impact to social and emotional feeling of the users. Azlina and Zulkiflee (2012) also mentioned that the existing landscape features always influenced peoples' physical activities.

Table 5: Factors that Encourage the Experiential Learning

\begin{tabular}{|c|c|c|c|c|c|}
\hline & Variables & Male & Female & $\mathbf{F}$ & Sig. \\
\hline 1 & The information/displays captured my interest & 4.18 & 4.14 & 0.609 & 0.818 \\
\hline 2 & I became interested in things that didn't previously interest me & 4.00 & 4.11 & 1.123 & 0.586 \\
\hline 3 & The information made me want to learn & 4.36 & 4.14 & 0.073 & 0.241 \\
\hline 4 & The information was presented in an interesting way & 4.27 & 4.08 & 0.079 & 0.299 \\
\hline 5 & I was reminded of something I already knew or had experienced & 4.45 & 4.26 & 0.955 & 0.219 \\
\hline 6 & I had the opportunity to participate actively & 4.00 & 3.85 & 1.677 & 0.513 \\
\hline 7 & The information was surprising or unexpected & 4.18 & 3.82 & 0.158 & 0.059 \\
\hline 8 & The information was new to me & 4.23 & 3.94 & 0.260 & 0.106 \\
\hline 9 & I was able to discuss the information with a new companion & 4.23 & 4.02 & 0.773 & 0.270 \\
\hline 10 & The information appealed to my emotions & 4.14 & 3.74 & 0.015 & $0.037^{*}$ \\
\hline 11 & The information appealed to my imagination & 4.33 & 3.94 & 2.479 & $0.022^{*}$ \\
\hline 12 & I had the opportunity to ask questions & 4.00 & 3.45 & 1.102 & $0.017^{*}$ \\
\hline 13 & I was able to see the real things or places the information referred to & 4.41 & 4.08 & 0.298 & 0.070 \\
\hline
\end{tabular}

Source: Researchers (2016)

Likert scale:

1 =Not important; 2 =Less important; 3= Moderate Important; 4=Important; 5= Very Important

*Significant different at $P<0.05$

\subsection{Respondents' Satisfaction Level}

The Cronbach's Alpha value for this analysis is 0.9 . There is no significant differences were detected between the male and female respondents under Table 6 . It can be concluded that all of these factors gave similar opinion to the respondents. However, the highest mean results for the above analysis shows that the male respondents rated high to 'I feel benefited from having come here today' with mean $=4.59$ while female respondents rated high to 'If I had the opportunity, 'I would like to come back here again' with mean=4.49. The male respondents gave low rated to 'I found the garden's information was very helpful' with mean= 4.18, while the female respondents have chosen ' $\mathrm{am}$ able to study the plants in more details' with mean $=4.11$.

Table 6: Respondents' Satisfaction Leve

\begin{tabular}{|c|c|c|c|c|c|}
\hline & Variables & Male & Female & $\mathbf{F}$ & Sig. \\
\hline 1 & I feel I benefited from having come here today & 4.59 & 4.32 & 0.732 & 0.097 \\
\hline 3 & The visit produced positive effect as I had hoped & 4.41 & 4.18 & 0.504 & 0.172 \\
\hline 4 & I love the landscape and garden design & 4.45 & 4.37 & 0.315 & 0.589 \\
\hline 5 & I found the plants arrangement and species are outstanding & 4.32 & 4.23 & 0.034 & 0.646 \\
\hline 8 & If I had the opportunity, I would like to come back here again & 4.64 & 4.49 & 3.775 & 0.339 \\
\hline 9 & I am able to study the plants in more details & 4.27 & 4.11 & 0.783 & 0.423 \\
\hline 10 & Overall, I was satisfied with the visit & 4.45 & 4.35 & 1.543 & 0.555 \\
\hline
\end{tabular}

$$
\text { Likert scale: }
$$

1 =Not important; 2 =Less important; 3= Moderate Important; 4=Important; 5= Very Important

\subsection{Respondents' Opinion on Informational Signage and Educational Facilities}

The results of photograph assessment in table 7 shows that generally the respondents agree on the importance of informational signage and educational facilities. Based on the photographs, the highest mean rating (mean=1.52) is the photo of 'Floor with leaves pattern and scientific name'. The students possibly rated highest this picture because it is located in front of the visitor information centre where it provides initial learning of the plant species before entering the garden. According to Cooley (2016), a high level of satisfaction and enjoyment during outdoor education could give significant to learning experience. Hensen (2012) mentioned that when the landscape design students participate in outdoor learning environment setting, they will be more engaged in looking towards design features and elements.

The second highest mean rating (mean=1.61) is the photo of 'Plant tagging/labelling'. This picture is found to give attraction to the students since tagging the plants assisted the respondents in associating the plant species with their botanical information. The plant identification label is the most basic educational unit in the garden and the visitor experience is improved by these tagging and labeling. The value of the tagging of a plant is paramount to effectively managing and protecting the plant collections. These findings aligned with previous research done by Noriah et al, (2015), Packer (2004) and Peterson (2015) where visitors preferred to garden 
setting that rich with information and user friendly. The third highest mean rating (mean=1.63) is the photo of 'Plant specimen/herbarium'. A herbarium is a research collection of pressed, dried, and labeled plant specimens arranged by a classification scheme and act as a "library" of plant specimens. Herbarium specimens are references for plant identification and document plant locations, habitat, abundance, and flowering/fruiting periods. In studying the arboretums and plant sciences, the student should be exposed to an outdoor laboratory learning styles. According to Kolb (1984), knowledge should be created from a fundamental concrete. This is supported by Hansen (2012) where the students should learn on how to demonstrate their understanding by looking at the basic example before being able to extend their design thinking.

Table 7: Respondents' Opinion on Importance of the Informational Signage and Educational Facilities

\begin{tabular}{|c|c|c|c|c|}
\hline & Variables & $\mathbf{N}$ & Mean & Rank \\
\hline 1 & The dry fruit and seed collection & 87 & 1.64 & 4 \\
\hline 2 & The plant specimen/herbarium & 86 & 1.63 & 3 \\
\hline 3 & Floor with leaves pattern and scientific name & 86 & 1.52 & 1 \\
\hline 4 & General information about the Botanic Garden & 84 & 1.73 & 8 \\
\hline 5 & Information board at the Dipterocarp walk & 84 & 1.79 & 9 \\
\hline 6 & Information on how to read the plant label for visitor & 84 & 1.79 & 9 \\
\hline 7 & Garden's directory & 84 & 1.67 & 5 \\
\hline 8 & Directional Signage around the garden & 86 & 1.76 & 6 \\
\hline 9 & Signage for plant category & 86 & 1.76 & 6 \\
\hline 10 & Plant tagging/labelling & 85 & 1.61 & 2 \\
\hline
\end{tabular}

\subsection{Conclusion}

This study hopes to enrich users' learning experience in garden setting, and fill them with information. As stated under Chapter 36 of Agenda 21 (UNESCO, 1992), making environmental information also one of the strategies to increase public learning experience and it is also supported by the Botanic Garden Conservation International (1999). Besides contributes to the global significance as mentioned above, this study also offers better collaboration between education and landscape architectural field in Malaysia where it can stimulate students' awareness and building their garden's knowledge, especially related to nature environment studies. It is also aligned with research done by Abbas (2012) where the relationship between youth and environment is very important especially in developing countries for a better quality of life.

\section{Acknowledgements}

The research was funded by University of Technology MARA under the LESTARI research grant. The authors would like to thank Centre of Studies for Landscape Architecture and the students for continuous support and participation in this study. High appreciation also expressed to the management of Putrajaya Botanical Garden for the valuable input into this study and granting us permission to conduct our research at the study area.

\section{References}

Abbas, M.Y. (2012). Children, Youth \& Environments (CYE): Lessons for Developing Countries? Procedia - Social and Behavioral Sciences, 38, 15 -22.

Aziz, N.F. \& Said, I.(2012). The Trends and Influential Factors of Children's Use of Outdoor Environments: A Review. Procedia -Social and Behavioral Sciences, 38, $204-212$.

Azlina, Wan \& A., S, Zulkiflee (2012). A Pilot Study: The Impact of Outdoor Play Spaces on Kindergarten Children. Procedia - Social and Behavioral Sciences, 38,275 -283 .

Ballantyne, R., Packer, J. \& Hughes, K. (2008). Environmental Awareness, Interests and Motives of Botanic Garden Visitors: Implication for Interpretive Practice. Journal of Tourism Management, 29, 439-444.

Botanical Garden Conservation (1999), Retrieved from http://www. bgci.org

Calkins, M, (2012). The Sustainable Sites Handbook: A complete guide to the principles, Strategies and Practices fir Sustainable Landscape. NJ: John Wiley \& Sons. Inc.

Chavez, M \& Sharrock, S (2013). The Role of Botanic Gardens in Building Capacity for Plant Conservation. Journal of Botanic Gardens Conservation International, 10 (1), 3-7.

Clements, T.L., \& Dorminey, J. (2011). Spectrum Matrix: Landscape Design and Landscape Experience. Landscape Journal 30, 2-11.

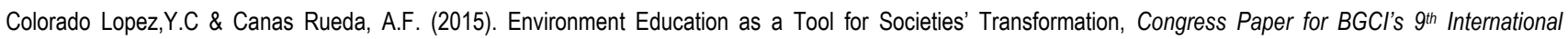
Congress on Education in Botanic Gardens, Botanical Garden Conservation International, 1, 38-44. 
Cooley, S.J., Burns, Victoria E, Cumming. \& Jennifer. (2016). Using Outdoor Education Adventure to Develop Students' Grouping Skills: A Qualitative Exploration of Reaction and Learning. Journal of Experiential Education, 39, 329-339

Corona Callejas,N.E \& Martinez Gonzalez, L. (2015). Evolving a Functional Education System for the Conservation of Mexican Flora in National Botanic Gardens, Congress Paper for BGCl's $9^{\text {th }}$ International Congress on Education in Botanic Gardens, Botanical Garden Conservation International, 1, 50-56.

Corraliza, J.A.,Collado, S.\& Bethelmy, L. (2012). Nature as a Moderator of Stress in Urban Children. Procedia - Social and Behavioral Sciences, 38,253 -263.

de Souza Silva, R. R., \& Biondi, D. (2013). Assessment of Landscape Preference in the Botanical Garden of Curitiba, Paraná, Brazil. Revsbau, Piracicaba - SP, .8(1), $37-50$.

Hensen, G. (2012). When Students Design Learning Landscapes: Designing for Experiential Learning through Experiential Learning. North American Colleges and Teachers of Agriculture Journal, 56, 30-35.

Heinrich, W.F., Habron, G.B, Johnson, H.L \& Goralnik, L. (2015). Critical Thinking Assessment across Four Sustainability-Related Experiential Learning Settings. Journal of Experiential Education, 38, 373-393.

Hilma, T.T. \& Mohammad, D.L. (2016). Planning for Riverside Area as Water Tourism Destination to Improve Quality of Life. Procedia - Social and Behavioral Sciences, $2344,434-441$.

Kolb. D.A. (1984). Experiential Learning as the Source of Learning and Development. Upper Saddle River, NJ: Prentice Hall

Marlyana Azyyati, M, Hafazah, A.K \& Mohd faez, L. (2012). Evaluating the Shah Alam City Council on the Hierarchy of Neighborhood Open Space. Procedia - Social and Behavioral Sciences, 36, 456-465.

Mehdi K., \& Koorosh, A. (2015). Achievement to Environmental Components of Educational Spaces for Iranian Trainable Children with Intellectual Disability. Procedia Social and Behavioral Sciences, 201, 9-18

Noriah, O., Noralizawati, M., Mohd Hisham, A. \& Mohd Ali Waliyuddin, A. R. (2015). Landscape Visual Studies in Urban Setting and Its Relationship in Motivational Theory. Procedia Social and Behavioral Science, 170, 442-451.

Noriah, O., Noralizawati, M., Mohd Hisham, A. \& Mohd Ali Waliyuddin, A. R. (2015). Exploring Human Oriented Design in Selected Botanical Gardens in Malaysia. Procedia Social and Behavioral Science, 201, 191-200.

Packer, J. (2004). Motivational Factors and the Experience of Learning in Educational Leisure Settings (Unpublished doctoral thesis). Queensland University of Technology, Australia

Parks of Putajaya (2016), Retrieved from http://www. ppj.gov.my

Peterson, Kay, DeCato, Lisa, Kolb \& David, A. (2015). Moving and Learning: Expending Style and Increasing Flexibility. Journal of Experiential Education, $38,228-238$. United Nations Educational, Scientific and Cultural Organisation (UNESCO), Retrieved from http://ehc. unesco.org

Utama, G.B.R (2015). Botanical Garden as a Recreational Park: Balancing Economic Interest with Conservation. International Journal of Scientific \& Engineering Research, 6, 148-158. 